\title{
Variasi morfologi puparium Bemisa tabaci (Gennadius) (Hemiptera: Aleyrodidae) pada berbagai inang dan ketinggian tempat dari daerah endemik penyakit kuning cabai di Wilayah Sundaland
}

\author{
Morphological variations of Bemisia tabaci (Gennadius) (Hemiptera: \\ Aleyrodidae) puparia on various hosts and altitudes from endemic \\ areas of pepper yellow disease in Sundaland
}

\author{
Sat Rahayuwati ${ }^{1}$, Purnama Hidayat ${ }^{*}$, Sri Hendrastuti Hidayat ${ }^{2}$ \\ ${ }^{1}$ Fakultas Agro Teknologi, Universitas Prima Indonesia, Kampus III UNPRI \\ Jalan Danau Singkarak, Medan 20117 \\ ${ }^{2}$ Departemen Proteksi Tanaman, Fakultas Pertanian, Institut Pertanian Bogor \\ Jalan Kamper, Kampus IPB Dramaga, Bogor 16680
}

(diterima Juli 2019, disetujui Juli 2020)

\begin{abstract}
ABSTRAK
Bemisia tabaci (Gennadius) dikenal sebagai salah satu kutukebul vektor virus gemini yang bersifat polifag. Identifikasi $B$. tabaci pada umumnya berdasarkan kantung nimfa instar keempat (puparium) yang memiliki mata berwarna merah. Bentuk nimfa instar keempat tersebut memiliki variasi morfologi. Adanya variasi morfologi ini menyebabkan kesulitan dalam identifikasi tingkat spesies. Penelitian ini bertujuan untuk mempelajari variasi puparium $B$. tabaci pada tanaman inang di berbagai ketinggian tempat di atas permukaan laut. Sampel puparium B. tabaci diperoleh dari daerah endemik di Wilayah Sundaland penyakit kuning cabai di Sumatera Barat, Jawa Barat, Jawa Tengah, Jawa Timur, Bali, dan Kalimantan Selatan. Sebelum dilakukan analisa morfologi, puparium terlebih dahulu dilakukan uji molekuler dan dinyatakan sebagai $B$. tabaci. Puparium kemudian dipreparasi dalam preparat mikroskop dan dilakukan identifikasi morfologi pada level spesies. Selanjutnya dilakukan pengamatan ukuran dan bentuk puparium serta pengamatan jumlah seta dorsal dan ukuran seta kauda. Analisis korelasi kanonik digunakan untuk mengetahui faktor yang mempengaruhi variasi puparium. Ada empat kelompok bentuk puparium B. tabaci, yaitu oval, oval dengan 1-2 lekukan, oval dengan $>3$ lekukan, dan bentuk seperti kerang laut. Terdapat hubungan antara jenis tanaman inang dan variasi morfologi puparium. Trikoma yang ada di permukaan daun tanaman inang menyebabkan terjadinya variasi jumlah seta dorsal yang memanjang, variasi bentuk, dan ukuran puparium. Variasi puparium B. tabaci lebih dipengaruhi oleh jenis tanaman inang daripada ketinggian tempat di atas permukaan laut.
\end{abstract}

Kata kunci: Bemisia tabaci, ketinggian tempat, puparium, seta dorsal, trikoma

\begin{abstract}
Bemisia tabaci (Gennadius) is one of polyphagous whitefly that has been known as gemini virus vector. The identification of $B$. tabaci is carried out based on pupal case or puparium of red eye fouth stage. The morphological variation of $B$. tabaci puparium leads to the difficulties on species identification. This research was aimed to study the morphological variations of $B$. tabaci puparium that has been found in various host plants at various altitude. Samples of B. tabaci puparium were obtained from Sundaland endemic area of pepper yellow curl disease virus endemic areas including


West Sumatra, West Java, Central Java, East Java, Bali, South Kalimantan. Slides-mounted were made from puparium and then identification was carried out to species. Observations have been conducted on B. tabaci puparial size, puparial shape, number of elongated dorsal setae, and caudal setae size. Canonical correlation analysis was applied to determine the factors that affected the puparium morphological variation. Based on the results, there were four variations of puparium: oval, oval with 1-2 indentations, oval with more than 3 indentations, and sea shell shapes. The variation observed on dorsal setae number, puparial shape, and size of $B$. tabaci were supposed due to the induction of trichomes on the leaves surface. Puparium variations were affected by host plants instead of altitude.

Key words: altitude, Bemisia tabaci, dorsal setae, puparium, trichomes in leaves surface

\section{PENDAHULUAN}

Bemisia tabaci (Gennadius) (Hemiptera: Aleyrodidae) merupakan hama penting sebagai vektor penyakit virus gemini (Genus: Begomovirus, Famili: Geminiviridae) atau penyakit kuning pada cabai. Kehilangan hasil akibat penyakit kuning cabai tersebut sebesar 20-30\% (Brown \& Bird 1992), sedangkan kehilangan hasil di Indonesia lebih tinggi sebesar 20-100\% (Setiawati et al. 2007). B. tabaci menyebabkan dua kerugian, yaitu kerugian tidak langsung sebagai vektor 111 spesies virus dan kerugian langsung akibat aktivitas makannya yang menghisap cairan floem. B. tabaci bersifat polifagus di kawasan tropika dan subtropika dengan inang lebih dari 900 jenis tanaman (GISD 2015).

Identifikasi spesies $B$. tabaci pada umumnya berdasarkan karakter morfologi nimfa instar terakhir (instar keempat), akan tetapi hasil lebih akurat menggunakan kantung nimfa terakhir (puparium) yang ditinggalkan oleh imago (Malumphy 2004). Puparium tersebut memberikan bekas permanen nimfa yang sudah berkembang sebelumnya. Kutukebul B. tabaci memiliki siklus metamorfosis berupa telur, empat instar nimfa, dan imago. Nimfa instar keempat awal memiliki mata berukuran kecil, nimfa ini tidak berganti kulit, kemudian menjadi nimfa dengan mata besar berwarna merah. Seringkali terjadi kekeliruan dalam menyebutkan nimfa dengan mata merah ini sebagai fase pupa (GISD 2015). Karakter morfologi nimfa $B$. tabaci bervariasi dipengaruhi oleh kutikula dan trikoma yang ada di permukaan daun (Mound 1963; Malumphy 2004). Perring (2001) juga menyatakan bahwa variasi karakter morfologi nimfa $B$. tabaci dipengaruhi oleh tanaman inangnya. Variasi karakter morfologi inilah yang menyebabkan B. tabaci mempunyai 19 sinonim penamaan.
Klasifikasi tingkat spesies B. tabaci masih belum ada kesepakatan antar peneliti. B. tabaci dipercaya sebagai species complex yang terdiri atas barbagai biotipe (Perring 2001). Dinsdale et al. (2010) berpendapat bahwa $B$. tabaci bukan species complex, akan tetapi sebagai cryptic species complex yang terdiri atas 24 spesies, bahkan Tay et al. (2012) menyebutkan terdiri atas 34 spesies. Evolusi bersifat kontinu sehingga proses pembentukan spesies baru mahluk hidup, termasuk kutukebul B. tabaci belum memperlihatkan perbedaan spesies dengan jelas secara morfologi. Salah satu proses evolusi pada $B$. tabaci diduga karena adanya isolasi geografi (De Barro 2005). Populasi yang berdekatan dapat berkopulasi serta menghasilkan keturunan fertil, tetapi populasi yang letak geografi jauh terjadi isolasi reproduksi. Cryptic species complex memiliki pengertian bahwa suatu populasi telah menjadi spesies yang berbeda walaupun bentuk morfologinya tidak mengalami perubahan (Cerca et al. 2019). Faktor yang menyebabkan terjadinya evolusi cryptic species complex, yaitu adaptasi yang berfokus pada fisiologi, tingkah laku, biokimia, dan bukan pada bentuk morfologinya.

Kutukebul B. tabaci biotipe B dan Q merupakan biotipe yang tersebar luas di seluruh dunia dan merupakan vektor virus yang efektif (Yao et al. 2017). Biotipe B dilaporkan ditemukan di Jawa Barat (Hidayat et al. 2008), akan tetapi survei yang lebih luas meliputi Kalimantan Selatan, Bali, Jawa Timur, Jawa Tengah, Yogyakarta, Jawa Barat, dan Sumatra Barat hanya ditemukan biotipe nonB yang termasuk dalam kelompok filogeografi Asia I (Rahayuwati et al. 2016). Lebih jauh Rahayuwati et al. (2016) memastikan bahwa identitas genetik B. tabaci dari lokasi-lokasi tersebut merupakan populasi yang tidak bervariasi dengan ditandainya hasil kladogram yang politomi. Hal yang sama, B. tabaci kelompok filogeografi Asia I juga 
ditemukan Firdaus et al. (2012) dari daerah Sumatera Barat, Jawa Barat, Jawa Tengah, Kalimantan Barat, Sulawesi Tengah. Walaupun tidak ditemukan biotipe $B$, ternyata kejadian penyakit kuning cabai di Indonesia mencapai $100 \%$ (Rahayu 2004; Setiawati et al. 2007). Diduga alel B. tabaci asal Thailand terintegrasi dengan alel B. tabaci asli Indonesia (De Barro et al. 2008) sehingga menjadi individu yang efektif menularkan penyakit Begomovirus pada cabai (De Barro 2005). Tidak ditemukannya populasi Biotipe B, seperti yang telah dilaporkan oleh Hidayat et al. (2008) sebelumnya, diduga karena populasi tersebut tidak berkembang (Rahayuwati et al. 2016).

Karakter morfologi puparium yang biasa digunakan untuk identifikasi spesies tidak dapat digunakan untuk membedakan perbedaan di bawah spesies B. tabaci yang dikenal sebagai species complex (De Barro et al. 2011). Walaupun begitu, ada banyak informasi dapat diperoleh dari keberadaan B. tabaci di lapangan. Diperkirakan populasi $B$. tabaci di pertanaman cabai mudah ditemukan dan jumlahnya melimpah. Namun, kenyataanya $B$. tabaci tidak hanya ditemukan pada pertanaman cabai, tetapi pada tanaman lain yang tumbuh di sekitarnya. Kutukebul spesies ini diduga memiliki preferensi pemilihan inang untuk meletakkan telur (Indrayani \& Sulistyowati 2005). Mound (1963) melaporkan beberapa inang B. tabaci, yaitu tembaku, singkong, kapas, centrosema atau butterfly peas, dan kacang kapri di Nigeria dan menemukan adanya variasi morfologi B. tabaci. Pada penelitian ini dilakukan pengamatan adanya variasi morfologi puparium $B$. tabaci pada 13 jenis tanaman inang.

Informasi mengenai variasi karakter morfologi B. tabaci yang ditemukan dari berbagai inang pada ketinggian tempat di atas permukaan laut di Indonesia di Wilayah Sundaland masih terbatas. Penelitian bertujuan untuk mempelajari variasi morfologi (bentuk dan ukuran puparium, panjang seta kauda, dan jumlah seta dorsal yang memanjang) pada puparium $B$. tabaci yang diambil dari berbagai tanaman inang serta pada berbagai ketinggian tempat di atas permukaan laut di daerah endemik penyakit kuning cabai.

\section{BAHAN DAN METODE}

\section{Pengambilan sampel puparium kutukebul}

Nimfa dan kantung instar terakhir (puparium) kutukebul diperoleh dari beberapa daerah endemik penyakit kuning cabai pada tahun 2008 (Tabel 1). Pengambilan sampel ini dilakukan pada pertanaman cabai dan tanaman lain yang tumbuh di sekitarnya. Nimfa dan puparium diperoleh dari daun dan sampel dikoleksi dalam alkohol $80 \%$.

Lokasi pengambilan sampel dikelompokkan ke dalam 5 ketinggian, yaitu A: 0-100 m dpl, meliputi Pesisir Selatan, Brebes, Rembang, Kediri, dan Hulu Sungai Selatan; B: 100-500 m dpl, meliputi Bogor, Malang, dan Badung; C: 500-700 m dpl, meliputi Malang; D: 700-1000 m dpl, meliputi Tabanan; E: 1000-1200 m dpl, meliputi Agam, Tanah Datar, Cianjur, Malang, dan Tabanan.

Tabel 1. Lokasi pengambilan sampel kutukebul dari daerah endemik penyakit kuning

\begin{tabular}{llcc}
\hline Provinsi & \multicolumn{1}{c}{ Kabupaten } & $\begin{array}{c}\text { Klasifikasi ketinggian tempat } \\
(\mathrm{m} \mathrm{dpl})\end{array}$ & Koordinat lokasi (LS; BT) \\
\hline Sumatra Barat & Pesisir Selatan & $0-100$ & 1,$225943 ; 100,462044$ \\
& Agam & $1000-1200$ & 0,$286784 ; 100,276215$ \\
& Tanah Datar & $1000-1200$ & 0,$409787 ; 100,555221$ \\
Jawa Barat & Cianjur & $1000-1200$ & 6,$737383 ; 107,065329$ \\
\multirow{2}{*}{ Jawa Tengah } & Bogor & $100-500$ & 6,$551076 ; 106,722722$ \\
& Rembang & $0-100$ & 6,$746707 ; 111,415685$ \\
Jawa Timur & Brebes & $0-100$ & 6,$969451 ; 109,015246$ \\
Bali & Malang & $100-500,500-700$, dan $1000-1200$ & 7,$826339 ; 112,446551$ \\
Kalimantan Selatan & Kediri & $0-100$ & 7,$910389 ; 112,113484$ \\
& Tabanan & $700-1000$ dan $1000-1200$ & 8,$562704 ; 115,114039$ \\
& Badung & $100-500$ & 8,$503668 ; 115,208478$ \\
\end{tabular}


Pembuatan preparat, identifikasi kutukebul, dan pengamatan morfologi

Pembuatan preparat dan identifikasi spesies berdasarkan karakter morfologi dikerjakan di Laboratorium Biosistematika Serangga, Departemen Proteksi Tanaman, Fakultas Pertanian, Institut Pertanian Bogor pada tahun 2017. Kutukebul yang teridentifikasi sebagai $B$. tabaci berdasarkan karakter morfologi tersebut, juga sudah dilakukan identifikasi secara molekuler (Rahayuwati et al. 2016). Identifikasi morfologi untuk memisahkan $B$. tabaci dengan spesies kutukebul lain menggunakan kunci identifikasi Martin (1987).

Preparat permanen B. tabaci yang sudah kering sekitar 2 minggu sejak dibuat, diamati karakter morfologi berupa variasi bentuk, ukuran panjang dan lebar puparium, panjang seta kauda, serta jumlah seta dorsal.

\section{Analisis data}

Hasil pengamatan karakter morfologi dianalisis korelasi kanonikal dan multivariate statistik (Klingenberg \& Maruqan-Lobon 2013) mengunakan program SPSS Inc. (2008), untuk membandingkan antar karakter morfologi dan membandingkannya dengan ketinggian di atas permukaan laut tempat sampel itu diambil.

\section{HASIL}

\section{Tanaman inang B. tabaci}

Pada penelitian ini, kutukebul $B$. tabaci ditemukan di ketinggian $1-1.200 \mathrm{~m}$ dpl yang pada survei ini diperoleh dari 13 jenis tanaman, yaitu buncis (Pisum sativum), labu (Cucurbita moschata), melon (Cucumis melo var. reticulates), terung (Solanum melongena), tomat (Solanum lycopersicum), gambas (Luffa acutangula), kacang merah (Vigna angularis), kedelai (Glycine max), mentimun (Cucumis sativus), cabai (Capsicum annum), kacang panjang (Vigna sinensis), kacang tanah (Arachis hypogaea), singkong (Manihot esculenta).

Selama pengamatan di lokasi tanaman cabai yang ditumpang sari dengan tanaman lain yang memiliki trikoma banyak, seperti tanaman terung, melon, buncis, dan tomat di Malang (Jawa Timur), B. tabaci memilih tanaman selain tanaman cabai sebagai tempat hidup. Walaupun B. tabaci tidak ditemukan pada tanaman cabai, kejadian penyakit kuning tetap ditemukan di Malang. Untuk lokasi Tabanan dan Badung, Bali, komoditas cabai ditanam di tengah areal persawahan. Dalam kondisi itu, B. tabaci memilih untuk berdiam di tanaman cabai dibandingkan tanaman padi. Pada hamparan tanaman cabai yang ditanam di dekat hamparan tanaman singkong di Rembang Jawa Tengah, B. tabaci ditemukan baik pada tanaman cabai maupun tanaman singkong.

\section{Hubungan tanaman inang dengan morfologi puparium}

Tekstur permukaan daun tanaman inang $B$. tabaci dapat dikelompokkan menjadi 3, yaitu kelompok I (permukaan daun halus) terdiri atas kacang tanah, singkong, cabai, dan kacang panjang; kelompok II (permukaan daun kasar) terdiri atas kedelai, mentimun, gambas, dan kacang merah; dan kelompok III (permukaan daun kasar dan memiliki banyak trikoma) terdiri atas terung, buncis, tomat, labu, dan melon. Bentuk puparium B. tabaci yang berasal dari 13 jenis tanaman inang tersebut dapat dibedakan menjadi 4 kelompok, yaitu oval, oval dengan 1-2 lekukan, oval dengan $>3$ lekukan, dan berbentuk seperti kerang laut.

Bentuk puparium yang hidup pada tanaman inang kelompok I umumnya berbentuk oval (100\% pada kacang tanah; $95 \%$ pada singkong; $63,4 \%$ pada cabai; dan $62,3 \%$ pada kacang panjang). Bentuk puparium pada tanaman inang kelompok II terdiri atas bentuk oval, oval dengan 1-2 lekukan, dan oval dengan $>3$ lekukan. Rincian bentuk puparium kelompok II, yaitu $100 \%$ bentuk oval pada kedelai; $44,5 \%$ bentuk oval dan $55,5 \%$ bentuk berlekuk 1-2 dan berlekuk $>3$ pada mentimun; $100 \%$ bentuk berlekuk $1-2$ dan berlekuk $>3$ pada gambas; $100 \%$ bentuk berlekuk 1-2 dan berlekuk $>3$ pada kacang merah. Bentuk puparium yang hidup pada tanaman inang kelompok III umumnya oval $>3$ lekukan dengan rincian $46,7 \%$ pada terung; $60 \%$ pada buncis; $62,5 \%$ pada labu; dan $100 \%$ pada melon. Puparium berbentuk kerang hanya ditemukan di tanaman terung yang termasuk dalam kelompok III.

Puparium yang hidup pada tanaman inang kelompok I rata-rata tidak memiliki seta dorsal memanjang. Ada beberapa individu puparium mempunyai satu pasang seta dorsal memanjang, 
tetapi jumlah puparium tersebut sedikit. Puparium yang hidup pada tanaman inang dengan permukaan daun kasar mempunyai seta dorsal memanjang berjumlah 2-4 pasang. Puparium yang hidup pada tanaman inang dengan tekstur permukaan daun kasar dan memiliki banyak trikoma, menunjukkan karakter seta dorsal memanjang berjumlah tujuh pasang (Gambar 1).

\section{Hubungan antara jumlah seta dorsal, ukuran puparium, dan panjang seta kauda}

Seta dorsal selalu ditemukan pada permukaan dorsal puparium B. tabaci dengan jumlah 7 pasang baik dalam kondisi berukuran pendek atau memanjang (Gambar 2). Puparium B. tabaci memiliki seta dorsal yang memanjang hingga berjumlah 1, 2, 3, 4, 5, 6, atau 7 pasang.

Terdapat hubungan antara jumlah seta dorsal yang memanjang dan ukuran puparium. Jika jumlah seta dorsal yang memanjang semakin banyak maka ukuran puparium mengecil dan demikian sebaliknya, dengan nilai kanonikal -0,5789. Apabila panjang puparium memanjang maka lebar puparium juga melebar, ditunjukkan oleh nilai kanonikal 0,7999.

Variasi morfologi puparium B. tabaci dapat diamati pada jumlah seta dorsal dan ukuran puparium, sedangkan karakter panjang seta kauda menunjukkan ukuran yang seragam. Seta dorsal merupakan karakter paling bervariasi dengan nilai kanonikal $-0,9064$. Panjang puparium (nilai kanonik 0,8098) merupakan karakter yang lebih bervariasi dibandingkan dengan lebar puparium (nilai kanonik 0,5564). Panjang seta kauda tidak bervariasi karena nilai fungsi kanonik mendekati nol $(0,0511)$. Ukuran rata-rata puparium $B$. tabaci dari berbagai tanaman inang, yaitu lebar 0,438 $0,554 \mathrm{~mm}$; panjang $0,611-0,768 \mathrm{~mm}$; panjang seta kauda $0,085-0,118 \mathrm{~mm}$.

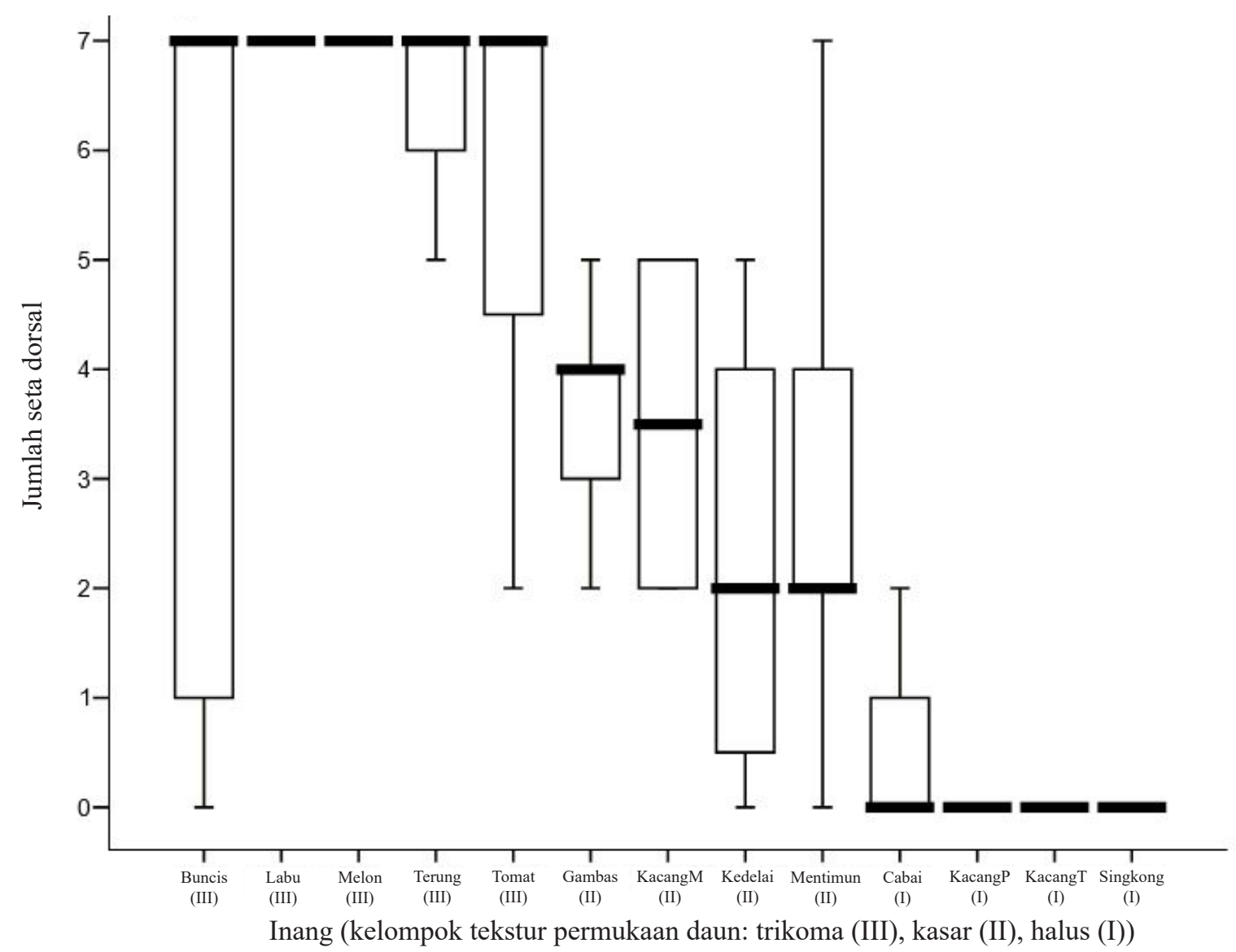

Gambar 1. Diagram boxplot jumlah seta dorsal berdasarkan nilai median (garis hitam) pada 13 tanaman inang Bemisia tabaci: Buncis (Pisum sativum), Labu (Cucurbita moschata), Melon (Cucumis melo var. reticulates), Terung (Solanum melongena), Tomat (Solanum lycopersicum), Gambas (Luffa acutangula), KacangM (Kacang merah = Vigna angularis), Kedelai (Glycine max), Mentimun (Cucumis sativus), Cabai (Capsicum annum), KacangP (Kacang panjang = Vigna sinensis), KacangT (Kacang tanah = Arachis hypogaea), Singkong (Manihot esculenta). 


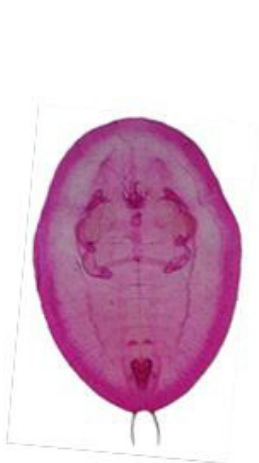

A

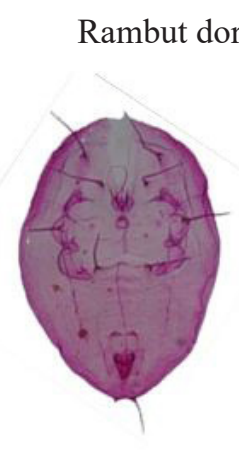

B

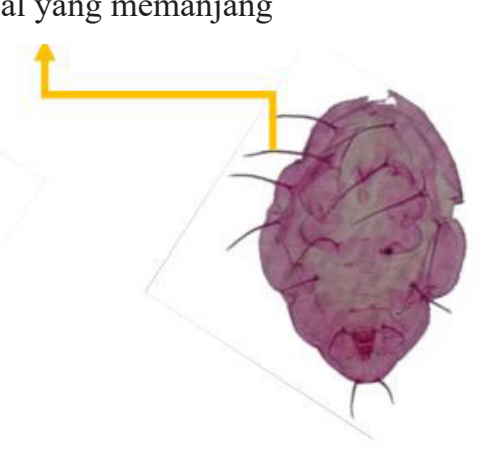

$\mathrm{C}$

Gambar 2. Seta dorsal yang memanjang berjumlah 0 pasang (A), 4 pasang (B), dan 7 pasang (C) yang ditemukan pada dorsal puparium Bemisia tabaci.

Hubungan ketinggian tempat terhadap jumlah seta dorsal, ukuran puparium, dan panjang seta kauda

Tidak terdapat hubungan antara ketinggian tempat dan variasi karakter morfologi $B$. tabaci (jumlah seta dorsal yang memanjang, ukuran puparium, dan panjang seta kauda). Spesies tanaman inang merupakan faktor utama yang menyebabkan variasi puparium (nilai kanonik 0,9262) dibandingkan dengan ketinggian tempat di atas permukaan laut (nilai kanonik 0,3296).

\section{PEMBAHASAN}

Kutukebul B. tabaci ditemukan dari ketinggian $1 \mathrm{~m}$ dpl hingga $1.200 \mathrm{~m}$ dpl. Enkegaard (1993) menyatakan bahwa semakin meningkat suhu lingkungan maka waktu perkembangan dari telur hingga dewasa $B$. tabaci semakin pendek, waktu untuk meletakkan telur semakin lama, tingkat kematian semakin rendah, dan fekunditas semakin tinggi. Suhu maksimum bagi $B$. tabaci berkembang biak adalah $32{ }^{\circ} \mathrm{C}$ hingga $35^{\circ} \mathrm{C}$, sedangkan suhu paling rendah untuk bertahan hidup adalah $16^{\circ} \mathrm{C}$.

Imago B. tabaci di lapangan tidak selalu ditemukan pada tanaman cabai. Jika di dekat pertanaman cabai hanya ada tanaman bukan inang, seperti tanaman padi maka baik pradewasa dan dewasa tetap berada di pertanaman cabai. Permukaan daun cabai halus, demikian juga permukaan daun singkong. Pada kasus seperti itu maka B. tabaci dapat ditemukan baik pada pertanaman cabai dan singkong. Jika di sekeliling pertanaman cabai terdapat tanaman dengan permukaan daun bertekstur kasar serta memiliki banyak trikoma, seperti terung, kedelai, melon, kacang merah, tomat, labu maka B. tabaci tidak ditemukan pada pertanaman cabai. Baik nimfa dan imago B. tabaci banyak ditemukan pada pertanaman dengan permukaan daun kasar serta memiliki trikoma tersebut. Lebih jauh keberadaan B. tabaci di lapangan dijelaskan oleh Indrayani \& Sulisyowati (2005) bahwa semakin tinggi kerapatan trikoma maka kolonisasi B. tabaci pada tanaman tersebut semakin meningkat. Permukaan daun cabai bertekstur halus sehingga ketika ada pilihan tanaman inang lain yang memiliki banyak trikoma maka $B$. tabaci akan memilih tanaman dengan banyak trikoma. Mc Auslane (2009) juga menyatakan bahwa $B$. tabaci tidak menyukai permukaan daun halus terutama untuk meletakkan telur.

Berbagai bentuk puparium ditemukan pada pengambilan sampel B. tabaci di daerah endemik penyakit kuning cabai, tetapi semua masih termasuk spesies yang sama (Martin 1987). Pemeriksaan 17 populasi B. tabaci oleh Rosell et al. (1997) dari seluruh dunia dengan cara mengamati karakter seta anterior submarginal, seta dorsal, seta posterior submarginal, seta kaudal, dan pinggiran trakea tidak didapatkan pohon filogeni yang parsimoni. Karakter morfologi tidak dapat digunakan untuk membedakan 17 populasi $B$. tabaci tersebut. Martin (1999) menyatakan bahwa bentuk puparium B. tabaci mempunyai berbagai variasi fenotipe bergantung pada karakter fisik permukaan daun, seperti lapisan lilin dan trikoma permukaan daun. Gill (2008) dan Mackenzie et al. (2001) menyatakan bahwa bentuk morfologi 
puparium Subfamili Aleyrodinae dapat mengalami perubahan karena pengaruh lingkungan.

Puparium B. tabaci yang hidup pada permukaan daun halus memiliki bentuk oval dan seta dorsal yang tidak memanjang. Puparium yang ditemukan pada permukaan daun kasar serta memiliki trikoma menunjukkan bentuk puparium berlekuk dengan seta dorsal memanjang dengan jumlah seta bervariasi. Mound (1963) juga menyatakan bahwa daun inang B. tabaci yang memiliki banyak trikoma menyebabkan bentuk nimfa tidak teratur, berlekuk bahkan lekukan sangat dalam hingga mengelilingi trikoma daun tanaman tersebut. Neil \& Bentz (1999) melakukan percobaan menetaskan nimfa $B$. tabaci pada permukaan daun halus maka seta dorsal nimfa tersebut tidak memanjang. Jika nimfa pertama diletakkan pada permukaan daun yang memiliki trikoma, pada daun dengan banyak partikel pengotor atau pada daun yang sudah penuh dengan nimfa lain maka seta dorsal nimfa tersebut akan memanjang.

Dalam penelitian ini, $B$. tabaci yang ditemukan pada berbagai inang mempunyai ukuran bervariasi. Berdasarkan analisis kanonikal, semakin panjang ukuran puparium maka lebarnya pun akan bertambah. Demikian pula sebaliknya, ukuran panjang puparium memendek maka lebarnya pun semakin berkurang. Watson (2007) juga menyatakan bahwa $B$. tabaci yang hidup pada inang dengan permukaan daun halus mempunyai ukuran puparium paling besar dan berbentuk oval. Semakin kasar dan banyak rambut di permukaan daun maka ukuran puparium juga semakin mengecil.

Perubahan fenotipe merupakan salah satu bentuk adaptasi. Adaptasi dapat diturunkan pada generasi berikutnya untuk membantu bertahan hidup pada lingkungan tertentu. Adaptasi meliputi perubahan tingkah laku, morfologi atau fisiologi (Mackenzie et al. 2001). Perubahan fenotipe juga dapat meningkatkan fitness suatu organisme (Monagan 2008; Otaki et al. 2010). Puparium B. tabaci berlekuk merupakan adaptasi agar bagian tubuhnya tidak tertusuk trikoma permukaan daun. Seta dorsal yang memanjang diduga bentuk adaptasi agar terhindar dari musuh alaminya. Seta dorsal puparium sekilas menyerupai trikoma pada permukaan daun. McFarland (1999) menyatakan tingkat kesamaan antara hewan dan latar belakang visual tempat hidupnya merupakan proses seleksi sehingga hewan dapat menghindar dari predator.

\section{KESIMPULAN}

Ada 4 macam bentuk puparium B. tabaci yang ditemukan, yaitu oval, oval dengan 1-2 lekukan, oval dengan $>3$ lekukan, dan berbentuk seperti kerang laut. Di lapangan B. tabaci lebih memilih hidup di tanaman dengan permukaan daun bertekstur kasar serta memiliki trikoma dibandingkan dengan berada di daun cabai. Variasi morfologi puparium B. tabaci lebih dipengaruhi oleh spesies tanaman inang daripada ketinggian tempat di atas permukaan laut

\section{UCAPAN TERIMA KASIH}

Penulis mengucapkan terima kasih kepada ACIAR (Australian Centre for International Agricultural Research) sebagai penyandang dana. Penelitian ini salah satu kajian vektor Geminivirus dalam payung besar penelitian penyakit kuning cabai di Indonesia.

\section{DAFTAR PUSTAKA}

Brown JK, Bird J. 1992. Whitefly-transmitted geminiviruses in Americas and the Caribbean Basin. Plant Diseases 72:220-225. https:// doi.org/10.1094/PD-76-0220. doi: https://doi. org/10.1094/PD-76-0220.

Cerca J, Meyer C, Stateczny D, Siemon D, Wegbrod J, Purschke G, Dimitrov D, Struck TH. 2019. Deceleration of morphological evolution in a cryptic species complex and its link to paleontological statis. Evolution 74:116-131. doi: https://doi.org/10.1111/evo.13884.

De Barro PJ. 2005. Bemisia tabaci from molecular to landscape. Proceedings of the International Seminar on Whitefly Management and Control Strategy. October 2005. FFTC ASAP. Taichung: Taiwan. Tersedia pada: https://www.fftc.org.tw/ htmlarea_file/library/20110712184749/tb171. pdf. [diakses 4 Mei 2020].

De Barro PJ, Hidayat SH, Frohlich D, Subandiyah S, Ueda S. 2008. A virus and its vector, pepper 
yellow leaf curl virus and Bemisia tabaci, two new invaders of Indonesia. Biological Invasions 10:411-433. doi: https://doi.org/10.1007/ s10530007-9141-x.

De Barro PJ, Liu SS, Boykin LM, Dinsdale AB. 2011. Bemisia tabaci: a statement of species status. Annual Review of Entomological 56:1-19. doi: https://doi.org/10.1146/annurevento-112408-085504.

Dinsdale A, Cook L, Riginos C, Buckley YM, De Barro P. 2010. Refined global analysis of Bemisia tabaci (Hemiptera: Sternorrhyncha: Aleyrodoidea: Aleyrodidae) mitochondrial cytrochrome oxidase I to identify species level genetic boundaries. Annals of the Entomological Society of America 103:196-208. doi: https:// doi.org/10.1603/AN09061.

Enkegaard. 1993. The poinsettia strain of the cotton whitefly, Bemisia tabaci (Homoptera: Aleyrodidae), biological and demographic parameters on poinsettia (Euphorbia pulcherrima) in relation to temperature. Bulletin of Entomological Research 83:535-546. doi: https://doi.org/10.1017/S0007485300039961.

Firdaus S, Vosman B, Hidayati N, Jaya Supena ED, Visser RG, van Heusden AW. 2012. The Bemisia tabaci species complex: Additions from different part of the world. Insect Science 20:723-733. doi: https://doi.org/10.1111/1744-7917.12001.

Gill RJ. 2008. Can molecules solve the Bemisia conundrum when morphology cannot? A taxonomist's perspective. Journal of Insect Science 8:1-53.

Global Invasive Species Database [GISD] 2015. Species profile Bemisia tabaci. Tersedia pada: http://www.iucngisd.org/gisd/species. php?sc=106 [diakses 25 April 2020].

Hidayat P, Aidawati N, Hidayat SH, Sartiami D. 2008. Tanaman indikator dan teknik RAPD PCR untuk penentuan biotipe Bemisia tabaci (Gennadius) (Hemiptera: Aleyrodidae). Jurnal Hama dan Penyakit Tumbuhan Tropika 8:1-7.

Indrayani IGAA, Sulistyowati E. 2005. Pengaruh kerapatan bulu daun pada tanaman kapas terhadap kolonisasi Bemisia tabaci Gennadius. Jornal Littri 11:101-106. doi: https://doi. org/10.21082/jlittri.v11n3.2005.101-106.

Klingenberg CP, Maruqan-Lobon J. 2013. Evolutionary covarian in geometric morphometric data: Analyzing integration, modularity, and allometry in a phylogenetic context. Sistematic Biology 62:591-610. doi: https://doi.org/10.1093/sysbio/syt025.
Mackenzie A, Ball AS, Virdee SK. 2001. Instant Note Ecology, $2^{\text {nd }}$ Ed. Oxford: Bios Science Publ Ltd.

Mc Auslane HJ. 2009. Common name: Sweetpotato whitefly $B$ biotype or silverleaf whitefly scientific name Bemisia tabaci (Gennadius) or Bemisia argentifolii Bellows \& Perring (Insecta: Hemiptera: Aleyrodidae). University of Florida EENY 129. Tersedia pada: http://entnemdept.ufl. edu/EENY-129 [diakses 21 December 2019].

McFarland D. 1999. Animal Behavior: Psychobiology, Ethology and Evolution. $3^{\text {th }}$ Ed. Malaysia: Longman.

Malumphy C. 2004. Diagnostic protocols for regulated pests, Bemisia tabaci. Bulletin OEPP/EPPO 34:281-288. doi: http://doi.org/ 10.1111/j.1365-2338.2004.00729.x.

Martin JH. 1987. An identification guide to common whitefly pest species of the world (Homoptera: Aleyrodidae). Tropical Pest Management 33:298-322. doi: http://dx.doi. org/10.1080/09670878709371174.

Martin JH. 1999. The Whitefly Fauna of Australia (Sternorrhyncha: Aleyrodidae): A Taxonomic Account and Identification Guide. Canbera: Commonwealth Scientific and Industrial Research Organisation (CSIRO).

Monagan P. 2008. Early growth conditions, phenotypic development and environmental change. Philosophical Transactions of the Royal Society of London, Series B 363:1635-1645. doi: http://doi.org/10.1098/rstb.2007.0011.

Mound LA. 1963. Host-correlated variation in Bemisia tabaci (Gennadius) (Homoptera: Aleyrodidae). Proceedings of The Royal Entomological Society of London 38:171-180. doi: http://doi.org/10.1111/j.1365-3032.1963. tb00746.x.

Neil JW,BentzJ. 1999. Evidence for the stageinducing phenotypic plasticity in pupae of the polyphagus whiteflies Trialeurodes vaporariorum and Bemisia argentifolii (Homoptera: Aleyrodidae). Annals Entomological Society of America 92:744. doi: ttps://doi.org/10.1093/aesa/92.6.774.

Otaki JM, Hiyama A, Iwata M, Kudo T. 2010. Phenotypic plasticity in the range-margin population of the Lycaenid butterfly Zizeeria maha. BMC Evolutionary Biology 10:252. doi: https://doi.org/10.1186/1471-2148-10-252.

Perring TM. 2001. Review article: The Bemisia tabaci species complex. Crop Protection 20:709-723. doi: https://doi.org/10.1016/s02612194(01)00109-0. 
Rahayu STS. 2004. Understanding The Flight Activity for Decision Making in Management of Bemisia tabaci. Tesis. Yogyakarta: Univesitas Gadjah Mada.

Rahayuwati S, Hidayat SS, Hidayat P. 2016. Identitas genetik Bemisia tabaci (Gennadius) (Hemiptera: Aleyrodidae) dari daerah endemik penyakit kuning cabai di Indonesia bagian barat berdasarkan fragmen mitokondria sitokrom oksidase I (mtCOI). Jurnal Entomologi Indonesia 13:156-164. doi: https://doi.org/ 10.5994/jei.13.3.156.

Rosell RC, Bedford ID, Frohlich DR, Gill RJ, Brown JK \& Markham PG. 1997. Analysis of morphological variation in distinct population of Bemisia tabaci (Homoptera: Aleyrodidae). Annals of the Entomological Society of America 90:575-589. doi: https://doi.org/10.1093/ aesa/90.5.575.

Setiawati M, Udiarto BK, Soetiarso TA. 2007. Selektivitas beberapa insektisida terhadap hama kutukebul (Bemisia tabaci Genn) dan predator Menochilus sexmaculatus Fabr. Jurnal Hortikultura 17:168-179. doi: http://dx.doi. org/10.21082/jhort.v17n2.2007.p\%25p.
SPSS Inc. 2008. SPSS statistics for windows, version 17.0. Chicago: SPSS Inc.

Tay WT, Evans GA, Boykin LM, De Barro PJ. 2012. Will the real Bemisia tabaci please stand up? Plos One 7:e50550. doi: https://doi.org/10.1371/ journal.pone.0050550.

Watson GW. 2007. Identification of whiteflies (Hemiptera: Aleyrodidae). Di dalam: APEC Reentry Workshop on Whiteflies and Mealybugs, (Kuala Lumpur, Malaysia, April 16-26 2007). Kuala Lumpur: Institute of Biological Sciences, University Malaya.

Yao FL, Zheng Y, Huang XY, Ding XL, Zhao JW, Desneux N, He YX, Weng QY. 2017. Dynamics of Bemisia tabaci biotypes and insecticide resistance in Fujian Province in China during 2005-2014. Scientific Reports 7:40803. doi: https://doi.org/10.1038/srep40803. 